\title{
Analysis of FGFR3 and HRAS genes in patients with bladder cancer
}

\author{
Ameneh Homami ${ }^{1}$, Zohreh Ataei Kachoei ${ }^{1}$, Mojgan Asgarie ${ }^{2}$, Farideh Ghazi*1 $\mathbb{D}$
}

Received: 31 Oct 2018

Published: 28 Aug 2020

\section{Abstract}

Background: Bladder cancer is the most frequent malignancy that affects the urinary tract. Studies have shown different types of FGFR3 and HRAS genes mutations in human bladder cancer, with a comprehensive range of mutation number in various populations. This study aimed to determine the specific point mutations of these 2 genes among Iranian patients with bladder cancer.

Methods: In this study, 100 specimens of patients with transitional cell carcinoma were analyzed. All samples were examined for FGFR3 and HRAS mutations using PCR and direct DNA sequencing methods.

Results: A total of 9 pathogenic mutations and 9 polymorphisms were found in 2 exons ( 7 and 15) of the FGFR3 genes in patients with bladder cancer (S249Y, I633I, L645L, D646E, Y647*, D628V, P250T, Q263H, Y305H). However, no mutation was found in exon 10 of FGFR3 and exon 1 of HRAS genes.

Conclusion: In this study, 5 mutations were found in FGFR3 gene that have not been detected previously. There was no mutation in exon 10 of FGFR 3 and exon 1 of HRAS. The results of this study confirmed the association of ethnic-genetic factors in the occurrence of bladder cancer, so that these variables may not be present in all ethnic groups.

Keywords: TCC, FGFR3, HRAS, FFPE, Touch down PCR

Conflicts of Interest: None declared

Funding: This study was supported by research committee foundation grant no 94-04-30-26586 of Iran University of Medical sciences.

\section{*This work has been published under CC BY-NC-SA 1.0 license. \\ Copyright $\odot$ Iran University of Medical Sciences}

Cite this article as: Homami A, Ataei Kachoei Z, Asgarie M, Ghazi F. Analysis of FGFR3 and HRAS genes in patients with bladder cancer. Med J Islam Repub Iran. 2020 (28 Aug);34:108. https://doi.org/10.47176/mjiri.34.108

\section{Introduction}

Bladder cancer (BC) is the most frequent malignancy of the urinary tract with high mortality. Bladder cancer accounts for approximately $3.2 \%$ of all cancers worldwide. Also, it is the seventh common cancer in the male population, as 386300 new cases are diagnosed with BC every year worldwide. However, it is less common in women. Some of the European countries, North America, and Northern Africa have the highest rate of bladder cancer and the incidence rates at age standardized urinary bladder cancer was determined at 14.5 in men and 2.4 in women in these 2 regions (2). This malignancy is usually diagnosed

Corresponding author: Dr Farideh Ghazi, ghazi.f@iums.ac.ir

1. Department of Medical Genetics and Molecular Biology, School of Medicine, Iran University of Medical Sciences, Tehran, Iran

2. Department of Medical Pathology, School of Medicine, Iran University of Medical Sciences, Tehran, Iran in old and middle-aged people (At the time of investigation 42 male and 58 female had bladder cancer.) (3).

$\mathrm{BC}$ accounts for $7.04 \%$ of all malignancies in Iran, based on the reports presented by the Cancer Office at the Noncommunicable Deputy of the Iranian Center for Disease Control and Prevention in 2005. This report has previously shown that the age-specific incidence rate of $\mathrm{BC}$ is $11.30 \mathrm{in}$ men and 2.86 in women in a population of 100000 Iranian patients with BC. Surprisingly, in some regions of Iran, the incidence of this cancer reaches to as high as 15.9 in a population of 100000 (4). Generally, tumors are classified as

\section{$\uparrow$ What is "already known" in this topic:}

A significant correlation exists between FGFR3 mutations and the incidence of bladder cancer. One of the objectives of such a study is to examine if the mutation detections are a beneficial tool for detecting bladder cancer to diminish the number of cystoscopical diagnosis.

\section{$\rightarrow$ What this article adds:}

According to the results of our study and those of previous studies, conducting studies on different Iranian ethnicities can be more useful. 
low-grade and high-grade. Bladder cancers are categorized as nonmuscle invasive or muscle invasive. Nonmuscle invasive bladder cancer (NMIBC) may progress to mucosa (Ta), submucosa (lamina propria) (T1), or flat CIS (Tis). Studies have shown that $25 \%$ of patients with BC present with a tumor progressing to the muscle layer of the bladder wall (T2-T4) (5).

Despite intensive therapy, $50 \%$ of patients with muscle invasive bladder cancer (MIBC) die from metastasis $(6,7)$. Evolutions in research and gene targeted therapies have shown that using receptor tyrosine kinase inhibitors in some types of cancer has stimulated the feasible cure of patients with MI-BC with similar adjuvant agents (8). As FGFR3 is the upstream of RAS genes, in noninvasive bladder cancers, mutations in the FGFR3 gene activate the RAS-MAPK pathway and increase growth signals (9). Roughly, these mutations are detected in $70 \%$ of low-grade $\mathrm{BC}$ and less in MIBC (10). Mutations in HRAS lead to inactive forms of RAS protein. In other words, RAS mutations harm GTPase activity, and thus the active GTP bound conformation is accumulated (11).

Recently, a Phase II study has examined the efficacy of an FGFR3 inhibitor in patients with MIBC. Most common somatic FGFR3 mutations in bladder malignancies occurred in exons 7,10 , and $15(12,13)$, and it frequently has been shown in low stage and grade tumors $(14,15)$. Some common mutations of FGFR3 gene that are involved in bladder cancer are shown in (Fig. 1) (16). Some studies have shown that an integration of HRAS and FGFR3 tests could identify many of primary tumors (17). The connections between these genes allowed managing this project with the goal of determining the frequency of mutations of these 2 genes in bladder tumors in Iran. When noninvasive papillary urothelial carcinoma ( $\mathrm{pTa}$ ) tumor is subjected to mutations, an invasive tumor may be formed. Therefore, this progress leads to formation of carcinoma in situ (CIS) that causes mutations in FGFR3 at the time of progression to invasive tumors. Analyzing larger groups of patients and conducting additional studies on the genetic profiles (loss of chromosome, gene amplifications, and some changes on p53) may help additional researches and eventually improve the treatments of patients with bladder cancer (18).

\section{Methods}

Patients and tumor samples: In this study, 100 urinary bladder transitional cell carcinoma cases from Shahid Hasheminejad hospital, Department of Pathology archives, were included in this study. Formalin-fixed paraffin embedded tumor tissue samples (FFPE) were collected from 100 patients who underwent TURBT (transurethral resection of bladder tumor). Among the 100 transitional cell carcinomas, 52 were graded as high and 48 as low. The mean age of the patients at diagnosis time was 63.78 in men and 67 in women. Of the patients, 86 were men (male/female ratio: 6/1). All transitional cell carcinomas were staged according to UICC (The Union for International Cancer Control) and graded according to WHO (world Health Organization) criteria.

\section{DNA isolation and mutation analysis}

Haematoxylin-eosin stained slides were used for histological analysis and served as templates for manual micro dissection from the respective tissue blocks. The dissected tumor samples contained a minimum of $70 \%$ tumor cells. Tumor samples were extracted from formalin-fixed paraffin embedded tumor tissue by dewaxing with xylene and ethanol. DNA was extracted from paraffin-embedded tissues using the QIAamp DNA Mini-Kit (Qiagen, Hilden, Germany), according to the manufacturer protocol. DNA quality and quantity were determined by nanodrop and gel electrophoresis. Then, PCR amplification was performed.

\section{PCR amplification}

Thermal cycling conditions for PCR were as follow: initial activation of DNA polymerase at $95^{\circ} \mathrm{C}$ for $2 \mathrm{~min}$, followed by 30 cycles of $95^{\circ} \mathrm{C}$ for $30 \mathrm{sec}$, annealing stage for $30 \mathrm{sec}$, and $72^{\circ} \mathrm{C}$ for $30 \mathrm{sec}$, with a final extension of $72^{\circ} \mathrm{C}$ for $5 \mathrm{~min}$. PCR cycling program for all samples were the same, except for annealing temperatures (Table 1).

PCR mix for each exon was prepared in a final volume of $25 \mu \mathrm{L}$ containing $2 \mu \mathrm{L}$ of genomic DNA, $1 \mu \mathrm{L}$ of each primer, $10 \mu \mathrm{L}$ of ddH2O, and $12 \mu \mathrm{L}$ of master mix. The PCR of FGFR3 exon 10 was optimized by running a touchdown PCR according to the protocol described in Table 2. Also, $5 \mu \mathrm{L}$ of PCR products were loaded into $1 \%$ agarose

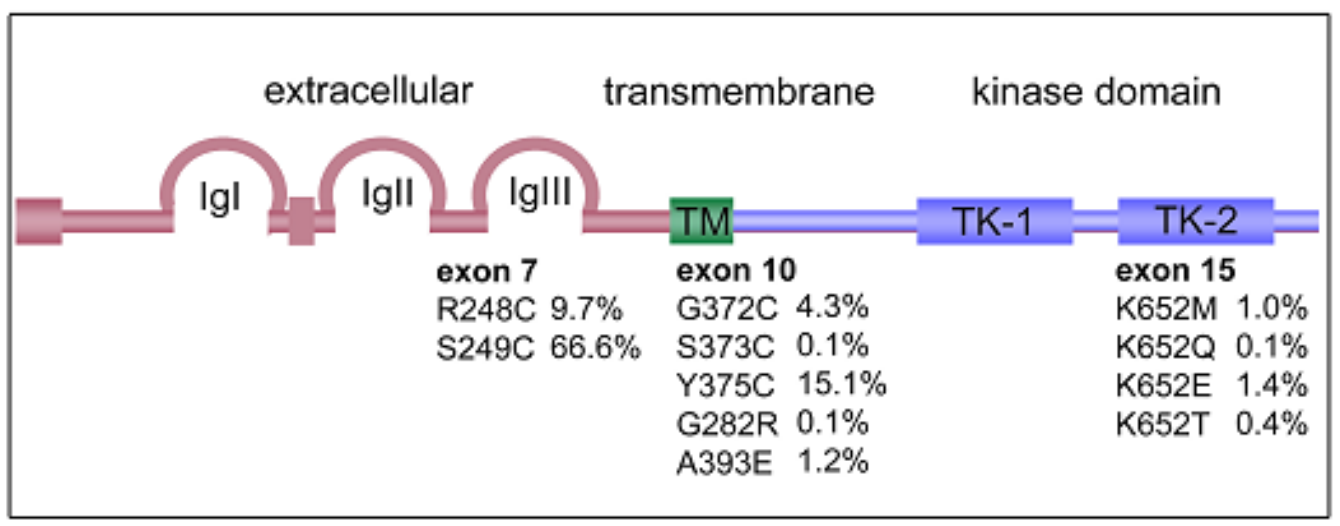

Fig. 1. Relevant frequencies and locations of FGFR3 mutations in urothelial carcinomas. Frequencies are the proportion of all FGFR3 mutations characterized to date. IgI, IgII, IgIII, immunoglobulin-like domains; TK-1, TK-2, split tyrosine kinase domain (1). 


\begin{tabular}{|c|c|c|c|}
\hline Gene/ exon/ codon & Primer sequence & $\begin{array}{l}\text { PCR product } \\
\text { size (bp) }\end{array}$ & $\begin{array}{l}\text { Annealing tem- } \\
\text { perature }\end{array}$ \\
\hline FGFR3/7/248,249 & F 5' CGGCAGTGGCGGTGGTGGTG 3' & $299 \mathrm{bp}$ & 68.5 \\
\hline FGFR3/10/372,375 & $\begin{array}{l}\text { R 5' CCAGCCCAGGAGCCCCAGCG 3' } \\
\text { F 5'CAACGCCCATGTCTTTGCAG 3' } \\
\text { R 5'AGGCGGCAGAGCGTCACAG 3' }\end{array}$ & $138 \mathrm{bp}$ & Touch down \\
\hline FGFR3/15/652 & $\begin{array}{l}\text { F 5'GACCGAGGACAACGTGATG 3' } \\
\text { R 5'GTGTGGGAAGGCGGTGTTG 3' }\end{array}$ & $160 \mathrm{bp}$ & 60 \\
\hline HRAS/1/12 & $\begin{array}{l}\text { F 5' GGAGACCCTGTAGGAGGACC 3' } \\
\text { R 5' GAGGAAGCAGGAGACAGGG 3' }\end{array}$ & $282 \mathrm{bp}$ & 62.2 \\
\hline
\end{tabular}

\begin{tabular}{lc} 
Table 2. Touch down PCR program for exon 10 FGFR3 \\
\hline Step 1 & $95^{\circ} \mathrm{C}, 2 \mathrm{~min}$ \\
\hline Step 2 & $95^{\circ} \mathrm{C}, 30 \mathrm{sec}$ \\
Step 3 & $65.3^{\circ} \mathrm{C}$ decrease $0.5^{\circ} \mathrm{C} \mathrm{per} \mathrm{cycle,} 30 \mathrm{sec}$ \\
Step 4 & $72^{\circ} \mathrm{C}, 20.0 \mathrm{sec}$ \\
Step 5 & Repeat steps $2-414 \mathrm{more}$ times \\
Step 6 & $95^{\circ} \mathrm{C}, 30 \mathrm{sec}$ \\
Step 7 & $58.3^{\circ} \mathrm{C}, 30 \mathrm{sec}$ \\
Step 8 & $72^{\circ} \mathrm{C}, 20.0 \mathrm{sec}$ \\
Step 9 & $72^{\circ} \mathrm{C}, 5$ min \\
Step 10 & Repeat steps $6-819$ more times \\
\hline
\end{tabular}
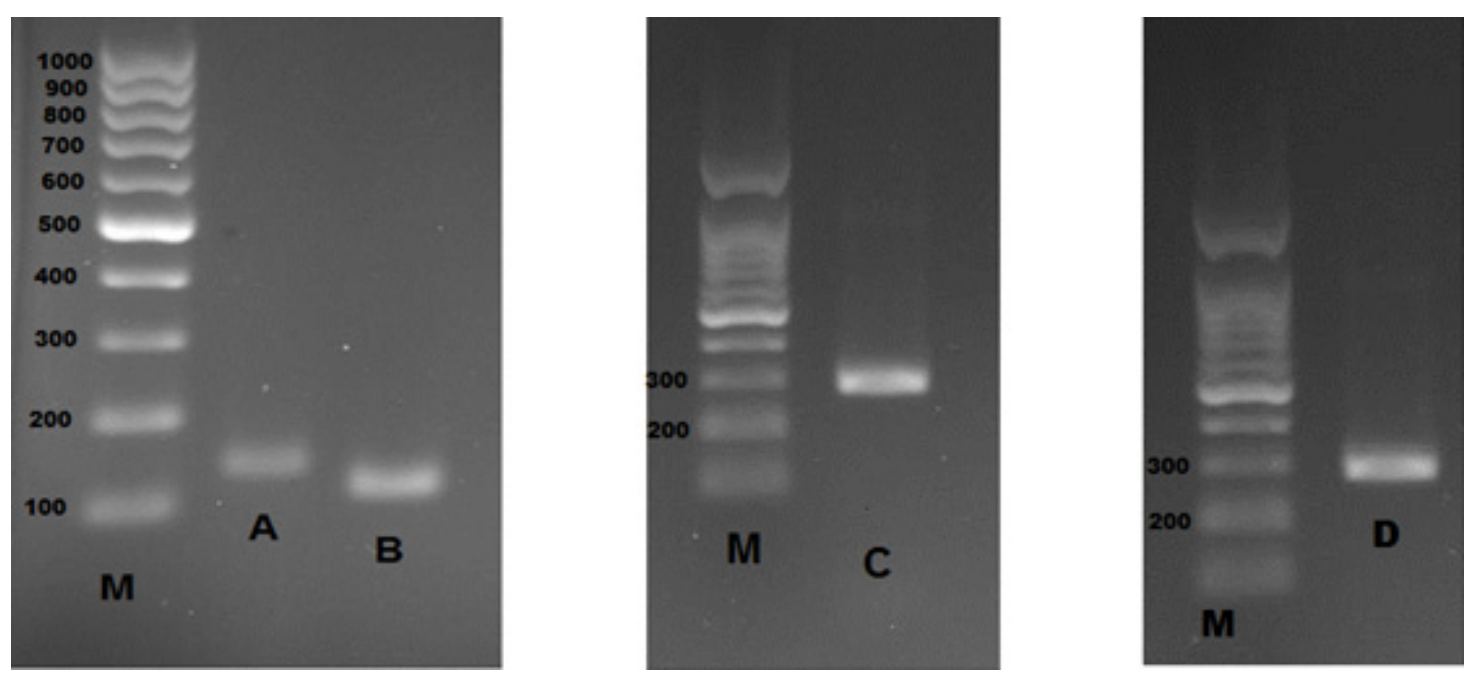

Fig. 2. PCR products bounds of FGFR3 exons 15,10 , and 7 and exon 1 of HRAS gene

M-Marker; A- exon 15 FGFR3 (160bp); B-exon 10 FGFR3 (138 bp); C-exon 7 FGFR3 (299 bp); D-exon 1 HRAS (282 bp).

gel and separated by electrophoresis in TBE buffer. The gels were visualized under UV illumination (Fig. 2).

\section{DNA sequencing}

Mutational analysis was done by direct sequencing of purified PCR products. After post PCR gel electrophoresis, they had very sharp bands without any unspecific bands or primer dimmers. Thus, the PCR products were Sanger's sequenced with forward and reverse primers by Sanger's method (Microgen company). The generated sequences were compared with the reported human FGFR3 and HRAS sequences obtained from the GenBank database. The GenBank accession numbers NG_012632 and NG_007666 were used as references for numbering the FGFR3 and HRAS alteration.

\section{Results}

Mutation analyses of the related exons were performed by PCR and DNA sequencing. In total, 100 formalin-fixed paraffin-embedded tumor tissue samples from patients with bladder cancer were studied. The results of these analyses identified 9 pathogenic mutations: D628V, Y647*, D646E, L645L, I633I, S249Y, Y305H, Q263, and P250T in exons 7 and 15 of FGFR3 gene (Table 3, Table 4, Fig. 3 and Fig. 4). The mutations were 6 missense, 2 synonymous and 1 nonsense. Also, 9 polymorphisms were identified in these exons. Among these mutations, 6 pathogenic mutations (S249Y, Q263H, Y305H, Y647*, D646E, and D628V) and 3 polymorphisms have not been reported previously, but 3 mutations and 4 polymorphisms have been identified previously.

\section{Discussion}

Bladder cancer is a common type of cancer that has a high incidence rate. However, despite good therapy options, a high recurrence rate is a major problem in noninvasive 


\begin{tabular}{|c|c|c|c|c|c|c|}
\hline HGVS Genomic Change & Driver Statement & Prediction index & Features & MamPhCons & MamPhyloP & $\begin{array}{l}\text { Phred } \\
\text { Score }\end{array}$ \\
\hline Chr4: $1803568 \mathrm{C}>\mathrm{A}$ & Predicted driver: tier1 & Disease-Causing & $\begin{array}{l}\text { Spl, pr af- } \\
\text { fected* }\end{array}$ & 0.999 & 1.9 & 22.9 \\
\hline Chr4: $1803570 \mathrm{C}>\mathrm{A}$ & Predicted passenger & Disease-Causing & $\begin{array}{l}\text { Spl, pr af- } \\
\text { fected* }\end{array}$ & 0.998 & 1.9 & 22.7 \\
\hline Chr4: $1803611 \mathrm{G}>\mathrm{T}$ & Predicted passenger & Disease-Causing & $\begin{array}{l}\text { Spl, pr af- } \\
\text { fected* }\end{array}$ & 1 & 1.9 & 23.8 \\
\hline Chr4: $1803704 \mathrm{~T}>\mathrm{C}$ & Polymorphism & Polymorphism & - & 0.94 & -1.001 & 2.721 \\
\hline Chr4: $1803735 \mathrm{~T}>\mathrm{C}$ & Predicted passenger & Disease-Causing & pr affected* & 1 & 1.575 & 23.7 \\
\hline
\end{tabular}

Table 4. Prediction of variants of exon15 in FGFR3 with different software

\begin{tabular}{|c|c|c|c|c|c|c|}
\hline $\begin{array}{l}\text { HGVS Genomic } \\
\text { Change }\end{array}$ & Driver Statement & Prediction Index & Features & MamPhCons & MamPhyloP & $\begin{array}{l}\text { Phred } \\
\text { Score }\end{array}$ \\
\hline $\begin{array}{l}\text { chr4: } \\
1807824 \mathrm{~A}>\mathrm{T}\end{array}$ & Predicted driver: tier1 & Disease-Causing & Spl, pr affected* & 1 & 1.668 & 26.9 \\
\hline $\begin{array}{l}\text { chr4: } \\
1807840 \mathrm{C}>\mathrm{T}\end{array}$ & Not protein affected & Disease-Causing & Spl, pr affected* & 0.285 & -1.681 & 14.4 \\
\hline $\begin{array}{l}\text { chr4: } \\
\text { 1807876C }>\mathrm{T}\end{array}$ & Not protein affected & Disease-Causing & Spl, praffected* & 0.77 & -1.959 & 11.03 \\
\hline $\begin{array}{l}\text { chr4: } \\
1807879 \mathrm{C}>\mathrm{A}\end{array}$ & Predicted passenger & Disease-Causing & Spl, pr affected* & 0.996 & 0.373 & 23.7 \\
\hline $\begin{array}{l}\text { chr4: } \\
1807882 \mathrm{C}>\mathrm{A}\end{array}$ & Predicted passenger & Disease-Causing & Spl, pr affected* & 1 & 0.946 & 38 \\
\hline $\begin{array}{l}\text { chr4: } \\
\text { 1807894G }>A\end{array}$ & Polymorphism & Polymorphism & Spl, pr affected* & 0.999 & 0.067 & 7.653 \\
\hline $\begin{array}{l}\text { chr4: } \\
\text { 1807915G }>\mathrm{T}\end{array}$ & Not protein affected & Polymorphism & Spl, pr affected* & 0 & 0.431 & 7.367 \\
\hline $\begin{array}{l}\text { chr4: } \\
\text { 1807922G }>A\end{array}$ & Polymorphism & Polymorphism & Spl, pr affected* & 0 & 0.176 & 1.103 \\
\hline $\begin{array}{l}\text { chr4: } \\
\text { 1807956C }>A\end{array}$ & Not protein affected & Polymorphism & Spl, pr affected* & 0.001 & 0.058 & 0.767 \\
\hline $\begin{array}{l}\text { chr4: } \\
\text { 1807964G }>A\end{array}$ & Not protein affected & Polymorphism & Spl, pr affected* & 0 & 0.698 & 0.074 \\
\hline $\begin{array}{l}\text { chr4: } \\
1807965 \mathrm{C}>\mathrm{A}\end{array}$ & Not protein affected & Polymorphism & Spl, pr affected* & 0 & 0.053 & 0.393 \\
\hline $\begin{array}{l}\text { chr4: } \\
\text { 1807966C }>A\end{array}$ & Not protein affected & Polymorphism & Spl, pr affected* & 0 & 0.007 & 0.609 \\
\hline $\begin{array}{l}\text { chr4: } \\
\text { 1807967T >A }\end{array}$ & Not protein affected & Polymorphism & Spl, pr affected* & 0 & 0.069 & 0.854 \\
\hline
\end{tabular}

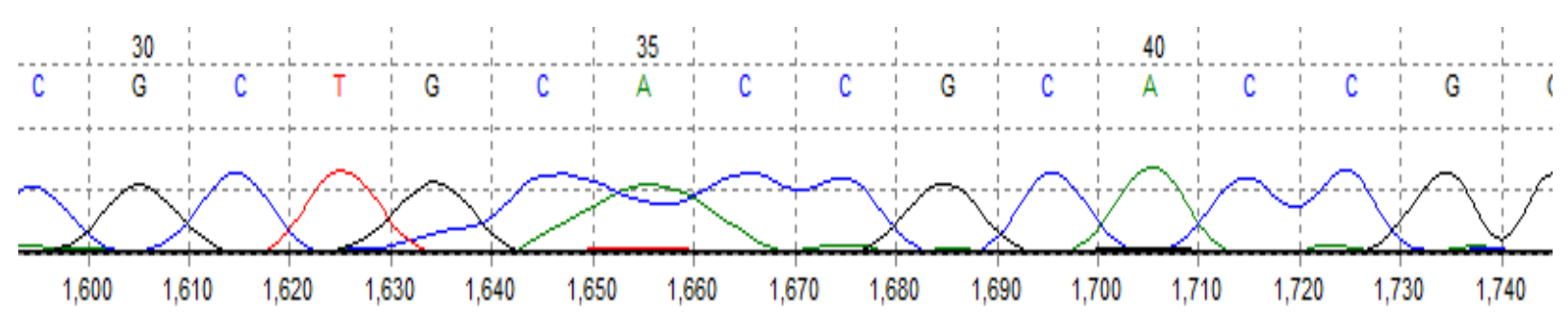

Fig. 3. Mutation p.S249Y in exon7. Patient number 54

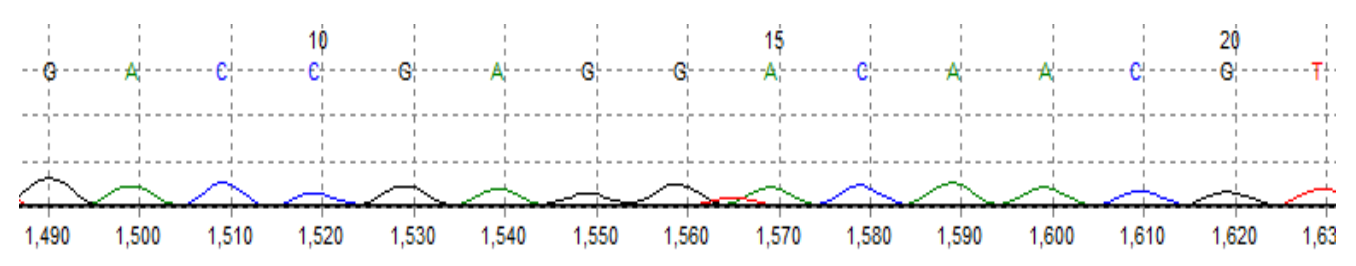

Fig. 4. Mutation p.D628V in exon15. Patient number 2

bladder cancer of low malignancy (19). Patients are monitored by cystoscopy for possible recurrence. Standard practice after TURB of bladder cancer is to screen patients with a cystoscopic examination for 2 years (20). Cystoscopy is an invasive high-cost method, so identification of some gene mutations as new biomarkers to improve the diagnosis 
and prognosis in patients with bladder cancer is highly important (21).

Somatic FGFR3 gene mutations have been observed in many bladder cancers. Illustration of the molecular pathways involved in $\mathrm{BC}$ is important for our understanding of the etiopathogenesis of the disease, more accurate diagnosis, precise prognosis, and better management of patients. Genetic variations related to tumorigenesis have accurate mutations and may have a potential as bladder cancer biomarker, with high specificity and sensitivity. Specific collected FGFR3 and HRAS mutations have been found to predominate in bladder cancer (22). Some biomarkers have been introduced for recognizing CSCs in many various solid tumors. Sedaghat et al reported that oct4 expression was correlated with advanced stages of bladder cancer. In this study, expression of another putative CSCs biomarker, CD133, was shown in bladder tumor with earlier stages that correlated with good prognosis (23).

The aim of this study was to determine the incidence of common FGFR3 mutations in bladder tumors in Iranian patients with BC. DNA sequencing of FFPE was used to identify gene mutations. The results of exon sequencing were analyzed with CADD search engine. For exon 7 and adjacent introns, 4 pathogenic mutations were found (phred score $>22$ ): $1803570 \mathrm{C}>\mathrm{A}, 1803735 \mathrm{~T}>\mathrm{c}, 1803568 \mathrm{C}>$ $\mathrm{A}$, and $1803611 \mathrm{G}>\mathrm{T}, 2$ of which $(\mathrm{T}>\mathrm{C}$ and $\mathrm{C}>\mathrm{A})$ were novel. Also, there was 1 polymorphism $(1803704 \mathrm{~T}>\mathrm{C})$ in intronic region that has been reported previously. For exon 15 and some parts of intron 15,5 pathogenic mutations were found (phred score $>11$ ): $1807824 \mathrm{~A}>\mathrm{T}, 1807840 \mathrm{C}>$ $\mathrm{T}, 1807876 \mathrm{C}>\mathrm{T}, 1807879 \mathrm{C}>\mathrm{A}$, and $1807882 \mathrm{C}>\mathrm{A}, 3$ of which $(1807824 \mathrm{~A}>\mathrm{T}, 1807879 \mathrm{C}>\mathrm{A}$, and $1807882 \mathrm{C}$ $>$ A) were novel. Moreover, 8 polymorphisms were detected in $1807894 \mathrm{G}>\mathrm{A}, 1807915 \mathrm{G}>\mathrm{T}, 1807922 \mathrm{G}>\mathrm{A}$, $1807956 \mathrm{C}>\mathrm{A}, 1807964 \mathrm{G}>\mathrm{A}, 1807965 \mathrm{C}>\mathrm{A}, 1807966$ $\mathrm{C}>\mathrm{A}$, and $1807967 \mathrm{~T}>\mathrm{A}, 5$ of which $(1807915 \mathrm{G}>\mathrm{T}$, $1807956 \mathrm{C}>\mathrm{A}, 1807965 \mathrm{C}>\mathrm{A}, 1807966 \mathrm{C}>\mathrm{A}$, and $1807967 \mathrm{~T}>\mathrm{A}$ ) have not been reported. However, no mutation was identified in exon 10 of FGFR3 and exon 1 of HRAS. Previous published studies worked on HRAS, but they could not detect any mutations in this gene (24). The rate and type of FGFR3 mutation in bladder cancer has not been sufficiently studied in Asia. In this study, bladder cancers of 100 Iranian patients were analyzed to identify the role of FGFR3 mutation in tumor progression.

\section{Conclusion}

In the present study, 9 pathogenic mutations and 9 polymorphisms were identified in exons 7 and 15 of FGFR3 gene, 11 of which have not been reported previously. The rate and type of FGFR3 mutations in bladder cancer has not been studied sufficiently in Asia. Thus, considering the results of this study and feasibility of the involvement of different etiological factors, it is recommended to perform this study on patients with bladder cancer from different Iranian groups and ethnicities for genetic diversity. Also, in these proposed studies, FGFR3 and HRAS should be studied in 2 groups of patients with low-grade and high-grade bladder cancer.

\section{Acknowledgments}

This study was supported by research committee foundation grant no 94-04-30-26586 of Iran University of Medical sciences. We thank the staff at the Departments of Genetics and Pathology at Iran University of Medical sciences.

\section{Conflict of Interests}

The authors declare that they have no competing interests.

\section{References}

1. Knowles MA. Role of FGFR3 in Urothelial Cell Carcinoma: Biomarker and Potential Therapeutic Target. World J Urol. 2007;25(6):581-93.

2. Jemal A, Bray F, Center MM, Ferlay J, Ward E, Forman D. Global cancer statistics. CA Cancer J Clin. 2011;61(2):69-90.

3. Shakhssalim N, Hosseini SY, Basiri A, Eshrati B, Mazaheri M, Soleimanirahbar A. Prominent bladder cancer risk factors in Iran. Asian Pac J Cancer Prev. 2010;11(3):601-6.

4. Mousavi SM, Gouya MM, Ramazani R, Davanlou M, Hajsadeghi N, Seddighi Z. Cancer incidence and mortality in Iran. Ann Oncol. 2009;20(3):556-63.

5. Homami A, Ghazi F. MicroRNAs as biomarkers associated with bladder cancer. Med J Islam Repub Iran. 2016;30:475.

6. Wu X-R. Urothelial tumorigenesis: a tale of divergent pathways. Nat Rev Cancer. 2005;5(9):713-25.

7. Cheng L, Zhang S, MacLennan GT, Williamson SR, Lopez-Beltran A, Montironi R. Bladder cancer: translating molecular genetic insights into clinical practice. Hum Pathol. 2011;42(4):455-81.

8. Black PC, Agarwal PK, Dinney CP, editors. Targeted therapies in bladder cancer - an update. Urologic Oncology: Seminars and Original Investigations; 2007: Elsevier.

9. Berrada N, Amzazi S, Abbar M, Ameur A, Khyatti M. Mutational Analysis of FGFR3 and HRAS Genes in Bladder Cancer and Washing Cell Sediments of Moroccan Patients. Epidemiology (sunnyvale). 2015;5(214):2161-1165.1000214.

10. Bakkar AA, Wallerand H, Radvanyi F, Lahaye J-B, Pissard S, Lecerf L, et al. FGFR3 and TP53 gene mutations define two distinct pathways in urothelial cell carcinoma of the bladder. Cancer Res. 2003;63(23):8108-12.

11. Trahey M, McCormick F. A cytoplasmic protein stimulates normal Nras p21 GTPase, but does not affect oncogenic mutants. Science. 1987;238(4826):542-5.

12. Tomlinson D, Baldo O, Harnden P, Knowles M. FGFR3 protein expression and its relationship to mutation status and prognostic variables in bladder cancer. J Pathol. 2007;213(1):91-8.

13. Gómez-Román JJ, Saenz P, González JC, Escuredo K, Santa Cruz S, Junquera $\mathrm{C}$, et al. Fibroblast growth factor receptor 3 is overexpressed in urinary tract carcinomas and modulates the neoplastic cell growth. Clin Cancer Res. 2005;11(2):459-65.

14. Martínez-Torrecuadrada JL, Cheung LH, López-Serra P, Barderas R, Cañamero M, Ferreiro $\mathrm{S}$, et al. Antitumor activity of fibroblast growth factor receptor 3-specific immunotoxins in a xenograft mouse model of bladder carcinoma is mediated by apoptosis. Mol Cancer Ther. 2008;7(4):862-73.

15. Knowles MA. Molecular pathogenesis of bladder cancer. Int J Clin Oncol. 2008;13(4):287-97.

16. Miyake M, Ishii M, Koyama N, Kawashima K, Kodama T, Anai S, et al. 1-tert-butyl-3-[6-(3, 5-dimethoxy-phenyl)-2-(4-diethylaminobutylamino)-pyrido [2, 3-d] pyrimidin-7-yl]-urea (PD173074), a selective tyrosine kinase inhibitor of fibroblast growth factor receptor-3 (FGFR3), inhibits cell proliferation of bladder cancer carrying the FGFR3 gene mutation along with up-regulation of p27/Kip1 and G1/G0 arrest. J Pharmacol Exp Ther. 2010;332(3):795-802.

17. Neal D, Mellon K. Epidermal growth factor receptor and bladder cancer: a review. Urol Int. 1992;48(4):365-71.

18. Villares G, Zigler M, Blehm K, Bogdan C, McConkey D, Colin D, et al. Retracted Article: Targeting EGFR in bladder cancer. World J Urol 2007;25(6):573-9.

19. Guancial EA, Werner L, Bellmunt J, Bamias A, Choueiri TK, Ross R, et al. FGFR3 expression in primary and metastatic urothelial carcinoma of the bladder. Cancer Med. 2014;3(4):835-44. 
20. Berrada N, Amzazi S, Abbar M, Ameur A, Khyatti M, Al-Bouzidi A, et al. Mutational analysis of FGFR3 and HRAS genes in bladder cancer and washing cell sediments of Moroccan patients. Epidemiology. 2015;5(4)

21. van Rhijn BW, Lurkin I, Radvanyi F, Kirkels WJ, van der Kwast TH, Zwarthoff EC. The fibroblast growth factor receptor 3 (FGFR3) mutation is a strong indicator of superficial bladder cancer with low recurrence rate. Cancer Res. 2001;61(4):1265-8.

22. Amzazi S, Abbar M, Ameur A, Khyatti M, Al-Bouzidi A, Attaleb M. Mutational Analysis of FGFR3 and HRAS Genes in Bladder Cancer and Washing Cell Sediments of Moroccan Patients. Epidemiology. 2016;2015.

23. Sedaghat S, Gheytanchi E, Asgari M, Roudi R, Keymoosi H, Madjd Z. Expression of Cancer Stem Cell Markers OCT4 and CD133 in Transitional Cell Carcinomas. Appl Immunohistochem Mol Morphol. 2017 Mar;25(3):196-202.

24. Karimianpour N, Mousavi-Shafaei P, Ziaee A-A, Akbari MT, Pourmand G, Abedi A, et al. Mutations of RAS gene family in specimens of bladder cancer. Urol J. 2008;5(4):237-42. 